\title{
Obstacles in SME Financing: The Case of Masko
}

\author{
Cem Berk $^{1 *}$ Recep Gultekin ${ }^{2}$ \\ 1. School of Applied Sciences, Kirklareli University, Luleburgaz Yerleskesi 39750 Luleburgaz / Kirklareli, \\ Turkey \\ 2. VakifBank, Bakirkoy Branch Zeytinlik Mah. Fahri Korutürk Cad. No: 19/A 34140 Bakırkoy Istanbul, \\ Turkey
}

\begin{abstract}
Small and medium sized enterprises (SMEs) have many benefits for the economy. They employ workforce, make investments, and pay taxes. Most of the time, they create innovative products that enhance competition. Therefore they can contribute to economy by providing innovative goods and services to the larger companies. However, they have short credit records and high risk as no concrete business is available. This kind of structure makes it difficult to finance projects if they don't have sufficient shareholders' equity. Bank loans are often not available, or they have high costs, bureaucracy and collateral requirements. Capital markets are also not accessible or provide low pricing for company stocks. Alternatives such as angel capital and crowd funding are available but they also have their limitations.

This research has the goal to identify obstacles in SME financing and propose solutions in this field. A survey is made in Masko, an organized industrial zone in Ikitelli region, Istanbul, Turkey. The number of completed surveys are 416. There are information on sampling, scaling, reliability, factor analysis and regression analysis in the research. With the regression analysis the main hypothesis of the research: Solution Proposals for Financing of SMEs is being affected by other dimensions of the study. is accepted. The significant dependent variables that affect SME Financing are the frequency of using financial vehicles and Information on Financial Vehicles. A discussion section on research findings elaborates these results as well as some demographic variables such as gender, age, education, business operating period, having a finance department, obtaining loans and duration of loans. Some of the solution proposals available in the conclusion are lifelong learning and innovation, adjustments to the banking system, tax incentives, and transparency.
\end{abstract}

Keywords: Corporate Finance, Furniture Industry, Regression Analysis, Small and Medium enterprises

DOI: $10.7176 /$ RJFA/10-20-11

Publication date:October $31^{\text {st }}, 2019$

\section{Introduction}

Entrepreneurship is an economic unit to satisfy the needs of others in order to obtain some kind of profit. (Dincer \& Fidan, 2000) In a digital world with the rapid advance in technology, data and information oriented solutions are often provided by SMEs. (Askin et al. , 2011)

Small and medium sized enterprises (or in short "SME) is defined under three categories according to the official definition in Turkey. A microbusiness has less than 10 staff and both balance sheet size and net revenues don't exceed $¥ 1$ Million (Turkish Lira). A small business has less than 50 staff and both balance sheet size and net revenues don’t exceed $₹ 8$ Million. And a medium sized business has less than 250 staff and both balance sheet size and net revenues don’t exceed ₹ 40 Million. (Official Newspaper no. 3143, 2005).

Due to relatively small size, and necessity to access funds in order to offer innovative funds, SME financing is crucial for social welfare. SME financing include equity and debt based solutions. Loans, subsidies and incentives, leasing and factoring, capital market solutions and barter are often used by SMEs however shareholders' equity is required upon foundation. The duration of loans are often short and medium term (except for equipment finance) in SME financing practice. (Aslan, 2006) The main reason for lack of external financing in SMEs is relatively high risk perception of investors and creditors. This often leads to high interest payments and low pricing of company stocks. (Cekceoglu, 2002)

New techniques have been developed in recent years such as angel capital and crowd funding. Angel capital is financing startups with innovative ideas. The technique is very risky and most of the firms financed by this technique fail, however those who succeed make this beneficial for the firms and investors. While financing, 
investors analyze investment idea and staff who will work in the project since there is no concrete and proven business by the time of investment. (Karabayir et al., 2012) Crowd funding is the collection of funds from many people through internet. This is most of the time a new business idea and the funds are often in the form of donations. (Zengin et al., 2012)

As Yilmaz (2007) points out the most important problem for SMEs is financing. Some major issues are necessity to provide equity as a startup capital, lack of access to loans, cost of loans, lack of collateral, limited incentives and grants, lack of favorable financing through capital markets and lack of consultancy / specialized staff on finance.

In this research a survey is available in organized industrial zone for furniture in Turkey. The firms are SMEs and obstacles in financing are evaluated through regression analysis. Sampling, reliability analysis, factor analysis and descriptive statistics are also available in the research.

The remainder of the paper is organized as follows. Chapter 2 provides a brief summary of some of the important works in this field. In Chapter 3, there is information on data and methodology of the study. A detailed explanation on survey regression is available in Chapter 4. Chapter 5 summarizes the discussion related to the research findings. And in Chapter 6, there are final remarks and solution proposals on the topic.

\section{Background}

Karaciboglu(2007) made a survey in the city Mugla ( located in the west coast of Turkey) to find out the reasons for the problems in SME financing. According to the results, most of the respondents are family companies, the owners and managers lack the necessary background for financing decisions and there is lack of knowledge on the use of financial vehicles.

Kaya (2014) focused on 30 companies in the organized industrial zone in the city Elazig. (Located in east Turkey). According to the results SMEs have inadequate equity, lack of advances in technology due to inadequate access to external capital, and they even aren't able to make the investments required for their basic operations.

Kutlu and Demirci'nin (2007) argue that although there are many SMEs in Turkey, their contribution in the total production is limited. They claim that SMEs lose their competitive power, due to lack of equity, inability to follow recent trends in finance, low amount and high cost of loans, collateral problems, and lack of access to capital markets. They think that there should be incentives on SMEs and they should pay lower taxes. Also there should be increased audits to create a transparent working environments.

Hacievliyagil (2016) worked on the efficiency of incentives on SME financing through the data of Central Bank of Turkey and Banking Regulation and Supervision Agency. They argue that the cost of goods and services produced by the SMEs should be decreased, these goods can be supplied by government, and a favorable tax scheme should be created.

Y1lmaz'in (2007) studied SMEs in the Tourism industry with a special focus in the Bodrum region. (West coast of Turkey) The result show that despite advantages in the focus group in the access to incentives, they still have similar problems with other SMEs such as lack of adaptation to newly developed financing mechanisms.

\section{Data and Methodology}

For this research, a survey has been made in an organized industrial zone for furniture, Masko, business located in Ikitelli region of the city Istanbul. In the universe of the survey, there are 778 businesses and the total number of staff is 11.525 . With 5\% sampling error, 378 respondents are enough for 25.000 people. (Table 1) In the study the number of completed surveys is 416 . Since this exceeds, the minimum number of respondents for the universe, it can be concluded that sampling is appropriate in this survey. 
Table 1. Sampling according to the size of universe

\begin{tabular}{|c|c|c|c|c|c|c|c|c|c|}
\hline \multirow{2}{*}{$\begin{array}{l}\text { Size of } \\
\text { Universe }\end{array}$} & \multicolumn{3}{|c|}{ +- 0.03 Sampling Error (d) } & \multicolumn{3}{|c|}{+-0.05 Sampling Error } & \multicolumn{3}{|c|}{+-0.10 Sampling Error } \\
\hline & $\mathrm{p}=0.5$ & $\begin{array}{c}\mathrm{p}=0 \\
8\end{array}$ & $\mathrm{p}=0.3$ & $\mathrm{p}=0.5$ & $\mathrm{p}=0.8$ & $\mathrm{p}=0.3$ & $\mathrm{p}=0.5$ & $\mathrm{p}=0.8$ & $\mathrm{p}=0.3$ \\
\hline 100 & 92 & 87 & 90 & 80 & 71 & 77 & 49 & 38 & 45 \\
\hline 500 & 341 & 289 & 321 & 217 & 165 & 196 & 81 & 55 & 70 \\
\hline 750 & 441 & 358 & 409 & 254 & 185 & 226 & 85 & 57 & 73 \\
\hline 1000 & 516 & 406 & 473 & 278 & 198 & 244 & 88 & 58 & 75 \\
\hline 2500 & 748 & 537 & 660 & 333 & 224 & 286 & 93 & 60 & 78 \\
\hline 5000 & 880 & 601 & 760 & 357 & 234 & 303 & 94 & 61 & 79 \\
\hline 10000 & 964 & 639 & 823 & 370 & 240 & 313 & 95 & 61 & 80 \\
\hline 25.000 & 1023 & 665 & 865 & 378 & 244 & 319 & 96 & 61 & 80 \\
\hline 50000 & 1045 & 674 & 881 & 381 & 245 & 321 & 96 & 61 & 81 \\
\hline 100000 & 1056 & 678 & 888 & 383 & 245 & 322 & 96 & 61 & 81 \\
\hline 1000000 & 1066 & 682 & 896 & 384 & 246 & 323 & 96 & 61 & 81 \\
\hline 100 & 1067 & 683 & 896 & 384 & 245 & 323 & 96 & 61 & 81 \\
\hline
\end{tabular}

For scaling, Demir (2018) - Financial Problems of Businesses, and Akdag(2014) - Solution Proposals for Financing of SMEs have been used. Table 2 shows Cronbach Alfa Coefficients for the study. As shown in Table 2 the lowest coefficient is 0,833 . This is still in the high reliability category. The results show that the survey used in this research is highly reliable based on Cronbach Alfa value.

Table 2. Reliability Analysis

\begin{tabular}{|l|l|}
\hline & Cronbach Alfa Coefficient \\
\hline Coefficient & 0,965 \\
\hline The frequency of using financial vehicles & 0,956 \\
\hline Information on Financial Vehicles & 0,924 \\
\hline Loan Size and Duration & 0,833 \\
\hline Access to Loans & 0,899 \\
\hline Knowledge on Subsidies and Grants & 0,912 \\
\hline Attitude Towards Financing Problems & 0,931 \\
\hline Access to Loans & 0,955 \\
\hline Solution Proposals for Financing of SMEs & 0,926 \\
\hline
\end{tabular}

Table 1. Reliability Analysis - Reference Table

\begin{tabular}{|l|l|}
\hline Cronbach Alfa Value & Reliability Status \\
\hline $0,00<$ Cronbach Alfa coefficient $<0,40$ & Not Reliable \\
\hline $0,40<$ Cronbach Alfa coefficient $<0,60$ & Low Reliability \\
\hline $0,60<$ Cronbach Alfa coefficient $<0,80$ & Reliable \\
\hline $0,80<$ Cronbach Alfa coefficient $<1,00$ & Highly Reliable \\
\hline
\end{tabular}

Source: (Demirhan \& Hamurkaroğlu, 2016)

Factor Analysis for the scale Financial Problems of Businesses is given in Table 4. Factor analysis is an attempt to 
combine questions with similar goals under one heading. Factor analysis is applied when KMO values are high and Barlett statistic is significant. KMO value is between 0 and 1. Values closer to one reflect closer interaction between variables. In addition Barlett test statistics is significant when the result is less than 0,05. For Factor Analysis on Financial Problems of Businesses the KMO value is 0,842 in the Barlett test, and $p$ value is 0,00 which is less than 0,05. Therefore, for the Financial Problems of Businesses scale, factor analysis is appropriate.

Table 4. Factor Analysis on Financial Problems of Businesses

\begin{tabular}{|c|c|c|c|c|c|c|c|c|c|c|c|c|}
\hline & Factor & $\begin{array}{l}\text { Questi } \\
\text { on }\end{array}$ & Mean & SD & $\begin{array}{l}\text { Al } \\
\text { fa }\end{array}$ & F1 & F2 & F3 & F4 & F5 & F6 & F7 \\
\hline & & Q8 & 3,81 & ,982 & & ,7 & ,196 & ,210 & - & ,062 & , 168 &, 312 \\
\hline & & Q9 & 3,77 & 1,11 & & ,7 & ,244 & ,247 &, 061 & ,099 & , 113 &, 126 \\
\hline & & Q10 & 3,78 & 1,15 & & ,6 & ,169 & , 253 & ,118 & ,139 & ,331 & ,118 \\
\hline & $\bar{\Xi}$ & Q11 & 3,71 & 1,09 & & 6 & ,250 & ,240 & ,088 & ,038 & ,451 & - \\
\hline & . & Q12 & 3,74 & 1,07 & & 6 & , 177 & ,211 & ,132 & ,013 & ,473 &, 074 \\
\hline & $\overline{\bar{I}}$ & Q13 & 3,69 & 1,17 & &, 5 & ,252 & ,265 & ,196 & - & ,534 &, 110 \\
\hline & $=0$ & Q14 & 3,72 & 1,16 & &, 5 & ,040 & , 128 & ,181 &, 072 & ,610 & - \\
\hline & $\overline{\bar{y}}$ & Q15 & 3,64 & 1,23 & & 6 & ,047 & ,078 & ,098 & ,117 & ,534 & 042 \\
\hline & $\overline{0}$ & Q16 & 3,57 & 1,20 & & ,7 & , 010 &, 110 & ,247 & ,075 & , 139 & , 137 \\
\hline & $\mathscr{E}$ & QS1 & 3,67 & 1,19 & & ,7 &, 142 & ,011 & , 143 & ,226 & ,111 & ,137 \\
\hline & $\bar{\sigma}$ & Q18 & 3,65 & 1,24 & & ,7 & ,091 & , 138 & , 195 & , 132 & - & ,074 \\
\hline$\infty$ & 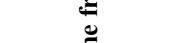 & Q19 & 3,67 & 1,05 & & , & ,171 & , 104 & 217 &, 115 & ,060 &, 123 \\
\hline 总 & $E$ & Q20 & 3,76 & 1,21 & 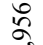 & 8 & , 193 & , 139 & ,207 & , 169 & - & - \\
\hline 狺 & 工 & Q21 & 3,75 & 1,24 & $\circ$ & 7 & ,286 & - & 217 & , 121 & ,069 & 001 \\
\hline 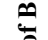 & & Q22 & 3,66 & 1,19 & &, 1 & ,084 & ,792 & ,187 & , 164 & ,097 & ,099 \\
\hline$\underline{E}$ & 馬 $\bar{g}$ & Q23 & 3,80 & 1,14 & & , & 145 & 803 & , 105 & - & , 140 & , 124 \\
\hline$\frac{\overline{0}}{2}$ & 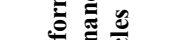 & Q24 & 3,79 & 1,20 & &, 2 & ,093 & ,827 & ,245 & ,237 & - & ,070 \\
\hline \pm & $\Xi$ & Q25 & 3,85 & 1,12 & $\stackrel{ \pm}{\leftrightarrows}$ &, 1 & , 144 & ,866 & ,109 & ,096 & - &, 059 \\
\hline $\bar{\pi}$ & 5 & Q26 & 3,91 & 1,18 & 0 & , 2 & ,091 & ,738 & ,112 & ,229 &, 166 & ,269 \\
\hline 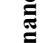 & & Q27 & 3,78 & 991 & & 3 & - & , 195 & - & ,313 & ,557 & ,380 \\
\hline & $\Xi \Xi \Xi$ & Q28 & 3,59 & 1,16 & & 1 & - & ,066 &, 153 & ,369 & $\begin{array}{l}, 573 \\
\end{array}$ & ,388 \\
\hline & 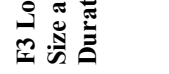 & Q29 & $\begin{array}{l}3,60 \\
82\end{array}$ & $\begin{array}{l}1,09 \\
888\end{array}$ & $\begin{array}{l}\hat{\tilde{O}} \\
0 \\
0\end{array}$ & $\begin{array}{l}2 \\
99\end{array}$ & -059 & ,016 & 089 & ,337 & ,506 & ,412 \\
\hline & & Q30 & 3,40 & 1,12 & &, 1 & ,193 & , 163 & ,198 & 825 & - & ,054 \\
\hline & 巳્d & Q31 & 3,51 & 1,16 & &, 1 & , 104 & , 184 & , 150 & ,898 &, 033 & ,070 \\
\hline & 岸早 & Q32 & $\begin{array}{l}3,70 \\
43\end{array}$ & $\begin{array}{l}1,11 \\
791\end{array}$ & $\begin{array}{l}\text { के } \\
\text { o. }\end{array}$ & $\begin{array}{l}, 2 \\
16\end{array}$ & $\begin{array}{l}- \\
, 009\end{array}$ & 139 & ,069 & ,785 & 288 & ,081 \\
\hline & & Q33 & 3,79 & 1,19 & &, 1 & ,300 & ,283 & ,630 &, 180 & ,244 & ,122 \\
\hline & $\stackrel{50}{E}$ & Q34 & 3,53 & 1,14 & &, 1 & ,070 & , 107 & ,887 &, 125 & ,070 & ,026 \\
\hline & $\frac{\pi}{3} \tilde{y}$ & Q35 & 3,67 & 1,17 & & ,3 & ,087 & ,282 & 669 & ,074 & ,131 & ,189 \\
\hline & 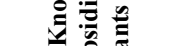 & Q36 & 3,65 & 1,17 & &, 4 & - & ,223 & ,655 & ,075 & - & ,261 \\
\hline & 㤐怠 & Q37 & $\begin{array}{l}3,57 \\
45\end{array}$ & $\begin{array}{l}1,14 \\
459\end{array}$ & ă & 58 & , 101 & ,139 & ,863 & ,127 &, 100 & ,069 \\
\hline & & Q38 & 3,94 & ,980 & &, 2 & 843 & ,093 & - & , 156 & ,053 & ,135 \\
\hline & & Q39 & 3,93 & ,963 & &, 1 & ,848 & ,040 &, 164 & ,052 & ,031 & ,174 \\
\hline & 氞 & Q40 & 3,94 & 1,04 & & , 1 & ,872 & ,084 & , 170 & - & ,217 & ,060 \\
\hline & 产 & Q41 & 4,00 &, 923 & &, 2 & 844 & , 142 & ,073 & ,037 & - & ,075 \\
\hline & $\approx 0$ & Q42 & 4,02 &, 972 & &, 1 & ,851 & ,079 & ,019 & - & ,065 & - \\
\hline & 吾 & Q43 & 3,86 & ,960 & & , & ,589 & ,214 & - & 351 & - &, 336 \\
\hline & 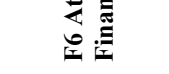 & Q44 & $\begin{array}{l}3,88 \\
46\end{array}$ & $\begin{array}{l}, 982 \\
33\end{array}$ & $\overrightarrow{\hat{\sigma}}$ & $\begin{array}{l}, 1 \\
86\end{array}$ &, 541 & ,230 & ,113 & ,389 & $-\bar{l}$ & ,407 \\
\hline & & Q45 & 4,04 & ,949 & &, 1 & ,392 & ,220 & ,168 & ,105 & , 106 & ,728 \\
\hline & పू & Q46 & 4,06 &, 924 & & 1 & ,278 & ,253 & ,212 & ,135 & , 100 & ,769 \\
\hline & 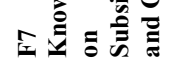 & Q47 & $\begin{array}{l}3,96 \\
39\end{array}$ & $\begin{array}{l}1,02 \\
553\end{array}$ & $\begin{array}{l}\hat{\alpha} \\
0 \\
0\end{array}$ & $\begin{array}{l}0 \\
97\end{array}$ & ,378 & ,392 & 291 & 101 & 291 & , 480 \\
\hline
\end{tabular}


Factor Analysis for the scale Solution Proposals for Financing of SMEs is given in Table 5. Barlett test is applied to check the applicability of factor analysis on the scale Solution Proposals for Financing of SMEs. According to the results, KMO value is computed as 0,882 and Barlett test $\mathrm{p}$ value is 0,00 which is less than 0,05 . Therefore, factor analysis is applicable for the scale Solution Proposals for Financing of SMEs.

Table 5. Factor Analysis on Solution Proposals for Financing of SMEs

\begin{tabular}{|c|c|c|c|c|c|}
\hline & & & & & Factor Loadings \\
\hline Factor & Question & Mean & SD & Alfa & F1 Solution Proposals for Financing of SMEs \\
\hline & Q48 & 3,7646 & 1,08312 & &, 851 \\
\hline 可 & Q49 & 3,7888 & 1,14266 & & 892 \\
\hline 20 & Q50 & 3,7913 & 1,19207 & 0,926 & ,918 \\
\hline 异 & Q51 & 3,7670 & 1,12873 & & 889 \\
\hline 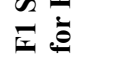 & Q52 & 3,8155 & 1,13770 & & 844 \\
\hline
\end{tabular}

The descriptive statistics for the demographic variables are given in Table 6 . The total number of respondents 416 . 169 respondents $(40,6 \%)$ are female. Most of the respondents belong to younger age groups. There are 169 people both in 18-23 and 24-39 age categories. The level of education is not very high. 141 respondents $(33,9 \%)$ are secondary school and 190 respondents $(45,7 \%)$ are high school graduates. Most of the respondents are from rather new firms. There are $257(61,8 \%)$ respondents in the 1-4 years business operating period category. 307 respondents $(73,8 \%)$ say that there is a finance department in their business. 263 respondents $(63,2 \%)$ are obtaining loans. 261 respondents $(\% 62,7)$ prefer short term loans.

Table 6. Descriptive Statistics for Demographic Variables

\begin{tabular}{|c|c|c|c|c|}
\hline & Level & Frequency & Percentage & $\begin{array}{l}\text { Cummulative } \\
\text { Percentage }\end{array}$ \\
\hline \multirow{2}{*}{ Gender } & Female & 169 & 40,6 & 40,6 \\
\hline & Male & 247 & 59,4 & 100,0 \\
\hline \multirow{5}{*}{ Age } & $18-23$ & 169 & 40,6 & 40,6 \\
\hline & $24-29$ & 169 & 40,6 & 81,3 \\
\hline & $30-35$ & 60 & 14,4 & 95,7 \\
\hline & $36-41$ & 10 & 2,4 & 98,1 \\
\hline & 42 & 8 & 1,9 & 100,0 \\
\hline \multirow{4}{*}{$\begin{array}{l}\text { Level of } \\
\text { Education }\end{array}$} & Primary School & 33 & 7,9 & 7,9 \\
\hline & Secondary School & 141 & 33,9 & 41,8 \\
\hline & High School & 190 & 45,7 & 87,5 \\
\hline & University & 52 & 12,5 & 100,0 \\
\hline \multirow{5}{*}{$\begin{array}{l}\text { Business } \\
\text { Operating } \\
\text { Period }\end{array}$} & 1-4 Years & 257 & 61,8 & 61,8 \\
\hline & 5-8 Years & 16 & 3,8 & 65,6 \\
\hline & 9-12 Years & 103 & 24,8 & 90,4 \\
\hline & 13-16 Years & 34 & 8,2 & 98,6 \\
\hline & 17 Years and More & 6 & 1,4 & 100,0 \\
\hline \multirow{2}{*}{$\begin{array}{l}\text { Finance } \\
\text { Department }\end{array}$} & Available & 307 & 73,8 & 73,8 \\
\hline & Not Available & 109 & 26,2 & 100,0 \\
\hline \multirow{2}{*}{$\begin{array}{l}\text { Obtaining } \\
\text { Loans }\end{array}$} & Yes & 263 & 63,2 & 63,2 \\
\hline & No & 153 & 36,8 & 100,0 \\
\hline \multirow{4}{*}{$\begin{array}{l}\text { Loan } \\
\text { Duration }\end{array}$} & Short & 261 & 62,7 & 62,7 \\
\hline & Medium & 20 & 4,8 & 67,5 \\
\hline & Long & 100 & 24,0 & 91,6 \\
\hline & None & 35 & 8,4 & 100,0 \\
\hline Total & & 416 & 100,0 & \\
\hline
\end{tabular}




\section{Regression Results}

The main hypothesis of the study is given below.

H0: Solution Proposals for Financing of SMEs is being affected by other dimensions of the study.

H1: Solution Proposals for Financing of SMEs is not being affected by other dimensions of the study.

To test the hypothesis, a regression analysis is given in Table 7 . The model $p$ value is 0,000 which is less than 0,05 . Therefore we can accept the null hypothesis under $5 \%$ level of significance. Solution Proposals for Financing of SMEs is being affected by other dimensions of the study.

Table 7. Regression for Solution Proposals for Financing of SMEs

\begin{tabular}{|c|c|c|c|c|c|c|}
\hline \multicolumn{7}{|c|}{$\mathrm{P}$ Value for Model Reliability is 0,000} \\
\hline Scale & Level & B & $\begin{array}{l}\text { Standard } \\
\text { Error }\end{array}$ & $\begin{array}{l}\text { Standard } \\
\text { B }\end{array}$ & T-Value & $\mathrm{p}$ Value \\
\hline \multirow{8}{*}{ 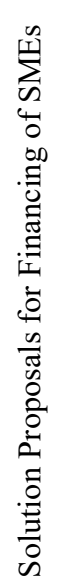 } & (Constant) & 1,083 & ,226 & & 4,785 &, 000 \\
\hline & TFOUFV & 625 & 059 & ,579 & 10,511 & ,000 \\
\hline & IOFV &, 123 & ,049 &, 126 & 2,512 & 012 \\
\hline & LSAD &,- 014 &, 056 &,- 013 &,- 246 & ,806 \\
\hline & ATL &,- 070 & 047 &,- 073 & $-1,503$ &, 133 \\
\hline & KOSAG &,- 009 & ,052 &,- 009 &,- 165 & ,869 \\
\hline & ATFP &, 065 & ,061 & 053 & 1,056 & ,292 \\
\hline & KOSAG2 &,- 002 & ,067 &,- 001 &,- 024 & ,981 \\
\hline
\end{tabular}

A multiple linear regression model is in the form $Y=\beta_{0}+\beta_{i} X_{i}+\ldots .+\beta_{n} X_{n}+\varepsilon_{i}$. In the formula $X_{i}$ is the ith independent variable and $\beta_{\mathrm{i}}$ is the coefficient for variable $\mathrm{i}, \varepsilon_{\mathrm{i}}$ is the error term for variable $\mathrm{i}, \beta_{\mathrm{o}}$ is the constant and $\mathrm{Y}$ is the dependent variable. Independent variable in the study is Solution Proposals for Financing of SMEs, whereas the dependent variables are TFOUFV: The frequency of using financial vehicles, IOFV: Information on Financial Vehicles, LSAD: Loan Size and Duration, ATL: Access to Loans, ATFP: Attitude towards Financing Problems and KOSAG: Knowledge on Subsidies and Grants.

According to Table 7 , the variables LSAD $(p=0,806)$, ATL $(p=0,133), \operatorname{KOSAG}(p=0,869)$, ATFP $(p=0,292)$ and KOSAG2 $(p=0,981)$ are not statistically significant in explaining Solution Proposals for Financing of SMEs. This is because $p$ values exceed critical limit under $5 \%$ level of significance $(p>0,05)$.

On the other hand, constant $(p=0,000)$, TFOUFV $(p=0,000)$ and IOFV $(p=0,012)$ are statistically significant in explaining Solution Proposals for Financing of SMEs. $(\mathrm{p}<0,05)$. The variables which are statistically signifant are shown in the regression equation. Since there are only two significant dependent variables, the equation is in the following form: $Y=\beta_{0}+\beta_{1} X_{1}+\beta_{2} X_{2}$.

The variables and coefficients are explained in Table 8 . The regression equation is therefore Solution Proposals for Financing of SMEs $=1,083+0,625 \mathrm{TFOUFV}+0,123 \mathrm{IOFV}$. Therefore there is a positive relation between TFOUFV and Solution Proposals for Financing of SMEs which means one unit increase in TFOUFV result 0,625 unit increase in Solution Proposals for Financing of SMEs. Similarly, there is a positive relation between IOFV and Solution Proposals for Financing of SMEs which means one unit increase in IOFV result 0,123 unit increase in Solution Proposals for Financing of SMEs. 
Table 8. Regression for Solution Proposals for Financing of SMEs

\begin{tabular}{|c|c|c|}
\hline Symbols & Meaning & Value \\
\hline $\mathbf{Y}$ & Dependent Variable & $\begin{array}{c}\text { Solution Proposals for Financing of } \\
\text { SMEs }\end{array}$ \\
\hline $\mathbf{X}_{\mathbf{1}}$ & Independent Variable & TFOUFV \\
\hline $\mathbf{X}_{\mathbf{2}}$ & Independent Variable & IOFV \\
\hline $\boldsymbol{\beta}_{\mathbf{0}}$ & Constant & 1,083 \\
\hline $\boldsymbol{\beta}_{\mathbf{1} \text { and }} \boldsymbol{\beta}_{\mathbf{2}}$ & Coefficient for Independent Variable & 0,625 and 0,123 \\
\hline
\end{tabular}

\section{Discussion}

The survey in this research has some important findings. First of all descriptive statistics are given. For gender, employing more females is beneficial since most of the people working in the finance department in Turkey are females. In addition, a balanced gender distribution will increase the efficiency in the business and would contribute with changing working patterns, increase in social interactions, and even create different perspectives when innovative thinking is required.

Similarly for age, employing young age group would have some benefits in making use of technology oriented financing opportunities, and following the recent trends in finance. However experience is also required in some financing decisions. Therefore a balanced strategy might be followed.

Education is crucial especially for staff in the finance department. People with better background could understand complex financing mechanisms much more easily. They can also be more successful in critical financing decisions.

For business operating period, it could be said that businesses with longer operating period, particularly those with good credit history have an advantage in trust and credibility. In addition, there can be indirect advantages such as staff commitment and corporate governance.

Having a finance department is often linked to company size where large companies do have a finance department and smaller companies do not. However an expert advice is certainly a benefit in avoiding the obstacles for SME financing.

There are many SMEs in the sample that don't use loans at all. But most of these companies might be interested in obtaining some debt if the costs, and collateral requirements are lower. In addition the preferred loan duration is very short because those with long duration are not available, which limits the success of SMEs. Projects with longer payback periods should be financed with long term funding.

Finally the regression result of the study reveal that there is a significant relationship between the dependent variable Solution Proposals for Financing of SMEs and independent variables The frequency of using financial vehicles and Information on Financial Vehicles. Therefore obstacles in SME financing are particularly linked with being informed and having the practice of using financial vehicles. This requires a structural change on financial and managerial perspectives.

\section{Conclusion}

SMEs are crucial in society both socially and financially. Many developed countries have therefore used incentives and grants to promote SMEs. In Turkey, there are attempts to advance the technology and enhance financing opportunities of SMEs in order to make them more competitive. (Uzunoglu et al., 2005)

Despite these, there are many weaknesses of SMEs in Turkey such as financial problems, intellectual capital and marketing. Difficulties in finding loans, cost of loans and collateral requirements make it difficult to access this type of funding. Instead they use shareholders' equity and they might sometimes use alternative financing such as financial leasing and factoring. (Temizkan \& Alkis , 2012)

Education is crucial for the success of SMEs. SMEs should emphasize lifelong learning and innovation in the organization. This would help attract better financing opportunities. The staff should be committed to work and 
SMEs should continuously try to attract talented workforce. For better financial solutions, SMEs might try to create their own financial departments. If this is not possible due to size of the company, they need to make sure that they get the expert advice for the financing alternatives.

In the macro level, the amount of loans allocated to SMEs should be increased and banking system should be adjusted to address the cost of debt, duration and collateral problems of the SMEs. Tax incentives, decreasing bureaucracy, and providing technological infrastructure are other possible solutions.

If tax levels are high, some SMEs might tend to make window dressing in order to represent lower sales values to pay low corporate tax. This attempt also decreases the credit rating since they don't show the actual financial strength in the balance sheet. Transparency would increase the loan obtaining capacity for the SMEs.

For further research, the research might be repeated in other cities and countries. Industry affect may also be available since different industries have different obstacles with SME financing. Other scales might also be developed on this topic. Empirical studies by using real data, could also add value to the literature.

\section{References}

Akdag, O. A. (2014). KOBI'lerin Finansman Sorunu ve Cozum Onerileri Ankara İli Uygulaması, Master's Thesis. Ankara: Turk Hava Kurumu Üniversitesi Sosyal Bilimler Fakültesi.

Aşkın, A. N., Vural, S. ve Ozgür, S. (2011). Tarihsel Surecte Girisimcilik Kavramı ve Gelisimi. Girisimcilik ve Kalkınma Dergisi, 6.2, 55-72.

Cekceoglu, Ç. (2002). Bir Finansman Modeli Olarak Risk Sermayesi ve Turkiye Uygulaması. Maliye Postasi. 530.

Demir, R. (2018). Turizm Sektöründe KOBİ'lerin Finansman Sorunları ve Cozum Onerileri, Master Thesis. Aydın: Adnan Menderes Üniversitesi Sosyal Bilimler Enstitusu.

Haydar Demirhan ve Canan Hamurkaroğlu, İstatistiksel Yöntemlere Giriş, Hacettepe Universitesi Yayınlarl, 3. Bask1, Ankara, 2016, s. 432.

Dinçer, O. ve Fidan, Y. (2000). İsletme Yonetimine Giris. İstanbul: Beta Basım Yayım Dagitim.

Hacievliyagil, N. (2016). KOBİ’lerin Finansman Sorununa Bir Çözüm Önerisi: Milli Ekonomi Modeli (MEM). Yönetim ve Ekonomi Araştırmaları Dergisi. 14.3, 32-50.

Karabayır, M. E. Gülşen, A. Z. Çifci, S. ve Haroon, M. (2012). Melek Yatırımcıların Yatırım Kararlarında Girisimci Odaklılığın Rolü:

Karacibioglu, S. R. (2007). KOBİ'lerin Finansman Sorunları ve Cozum Onerileri: Muğla Örneği, Master's Thesis. Aydın: Adnan Menderes Üniversitesi Sosyal Bilimler Enstitusu.

Kaya, G. A. (2014). Elazıg Ilinde KOBİ'lerin Finansal Sorunları ve Cozum Onerilerine Ilişkin Bir Araştırma. Fırat Universitesi Harput Araştırmaları Dergisi. 1.1, 193-224.

Kutlu, H. A. ve Demirci, N. S. (7-8 Aralık 2007). KOBI'lerin Finansal Sorunları ve Cozum Onerileri. 4. KOBI'ler ve Verimlilik Kongresi, İstanbul Kültür Üniversitesi, 187-198.

Kucuk ve Orta Buyuklukteki Isletmelerin Tanımı. Nitelikleri ve Sınıflandırılması Hakkında Yönetmelik. Official Newspaper no. 3143. Madde 5. (18.11.2005).

Temizkan, V. ve Alkış, H. (2012). KOBI'lerin Yonetsel Sorunlarının Cozumunde Japon Yonetim Sisteminin Rolu. Karabuk Universitesi Sosyal Bilimler Enstitüsu Dergisi. 3,1, 68-85.

Uzunoglu, S., Apak, S. ve Açıkgöz, A. F. (2005). AB Müzakere Sürecinde KOBI'lerin Korunması ve Uyum Stratejileri. İstanbul Ticaret Odası Yayını, Entegre Matbaacılık, İstanbul.

Yılmaz, H. (2007). Turizm Sektörü KOBI’lerinin Finansman Sorunlarının Diğer Sektörlerle Karșılaștırmalı Analizi: Bodrum Örneği. Muhasebe ve Finansman Dergisi. 33, 162-170.

Zengin, S. Yüksel, S. ve Kartal, M. T. (2017). Kitle Fonlaması Sisteminin Turkiye'ye Faydaları. Bankacılık ve Sermaye Piyasası Arastirrmaları Dergisi. 1.2, 22-32. 